\title{
Long-term storage and viability of Ochlerotatus albifasciatus eggs (Diptera: Culicidae)
}

\author{
Raúl E Campos \\ Instituto de Limnología “Dr. Raúl A. Ringuelet”, Universidad Nacional de La Plata, CC 712, (1900) La Plata, Buenos Aires, Argentina
}

The viability of Ochlerotatus albifasciatus (Macquart) eggs stored at room temperature and at $5^{\circ} \mathrm{C}$ was studied over 31 months. After 12, 18 and 31 months of storage, eggs were acclimatized at $22^{\circ} \mathrm{C}$ for ten days, and then inundated twice every seven days. The effect of the storage period on the percentage of hatching was analyzed by one way ANOVA. Differences on the hatching response between the first and second flooding were analyzed by paired t-test. Differences on the hatching response between the two storage conditions were analyzed by Mann-Whitney rank test. Results showed that (1) Oc. albifasciatus eggs were able to survive and hatch over 31 months; (2) the percent hatching of eggs stored at $5^{\circ} \mathrm{C}$ was higher than that of eggs stored at room temperature; and (3) low temperatures and long periods without water favor installment hatching.

Key words: Culicidae - floodwater mosquitoes - egg dormancy - diapause - egg survival - hatching

Ochlerotatus albifasciatus (Macquart) is a floodwater mosquito of medical importance (Mitchell et al. 1987) distributed from tropical Brazil (Forattini et al. 1988) to cold areas in Argentina (Rossi et al. 2006). Larval sites are temporary, semi-permanent and ephemeral pools, with a high variation in the water level (Maciá et al. 1995). As a consequence of the heterogeneous larval sites, Oc. albifasciatus eggs have adopted strategies that allow them to survive under unfavorable environmental conditions. When eggs are either immersed in cold water or remain dry they enter a quiescence or diapause (Campos \& Sy 2006, 2007). When environmental conditions turn favorable a proportion of the eggs hatch while others remain in dormancy until the next flooding (Campos \& Sy 2006). This behavior, characterized by the occurrence of partial hatchings, is called installment hatching, and has been interpreted as a reproductive strategy that permits multivoltine species that breed in ephemeral pools to survive for long periods (Andreadis 1990). Thus, installment hatching and resistance to low temperature and lack of water, permit Oc. albifaciatus survive in regions where rainfall and temperature are highly variable (Campos \& Sy 2007).

Several studies on Aedine mosquitoes, mainly from tree hole and container habitats, have been carried out to estimate egg survival (e. g., Christophers 1960). For example, Gubler (1970) estimated that Aedes albopictus (Skuse) eggs are able to survive for 243 days. On the other hand, studies on floodwater mosquitoes showed that Aedes

Financial support: Conicet grant PIP 700/98, 5928/06

+Corresponding author: rcampos@ilpla.edu.ar

Received 12 October 2007

Accepted 15 January 2008 and Psorophora eggs resist in dormancy for approximately four years (Breeland \& Pickard 1967), while Aedes vexans (Meigen) and Aedes sticticus (Meigen) eggs are able to survive for two years if the substrate remains moist (Gjullin et al. 1950). Survivorship of floodwater mosquito eggs has been studied from different regions all over the world, but is unknown from neotropical species.

The objective of this study was to determine the resistance of Oc. albifasciatus eggs to long dry periods, testing the hypothesis that Oc. albifasciatus eggs survive after a long dry period independently of storage temperature.

The experiment was carried out with eggs obtained from wild-caught females of Oc. albifasciatus captured with a manual aspirator at Pereyra Iraola Provincial Park $\left(34^{\circ} 51^{\prime} \mathrm{S} ; 58^{\circ} 08^{\prime} \mathrm{W}\right)$, province of Buenos Aires, Argentina, from May to June 2004. Mosquitoes were blood fed on a guinea pig and stored individually in tubes $(6 \mathrm{~cm}$ in height $\times 3 \mathrm{~cm}$ in diameter) with a moist piece of towel paper resting on a cotton pad at the bottom of the tube. After oviposition, females were withdrawn and the tubes sealed with plastic film to maintain humidity. Eggs remained at room temperature for over nine days to ensure complete maturity of embryos (Fava et al. 2001).

Batches (batch = group of eggs laid by a single female during one gonotrophic cycle) were pooled and randomly assigned to one of two treatments. Eggs from one treatment were kept at room temperature, and the other was stored in the dark at $5^{\circ} \mathrm{C}$. All batches with fungal or bacterial contamination during storage were excluded from the experiment.

After 12, 18, and 31 months of storage, 20 batches from each group were flooded except for the group of 18 months at $5^{\circ} \mathrm{C}$ where 19 batches were used. Batches were acclimatized for 10 days at $22^{\circ} \mathrm{C}$ and $12: 12 \mathrm{~h}$ lightdark photoperiod after flooding. To stimulate hatching, eggs were transferred to Petri dishes $(10 \mathrm{~cm}$ in diameter, $1.5 \mathrm{~cm}$ in height) containing $40 \mathrm{ml}$ of tap water and $10 \mathrm{mg}$ of yeast. After $24 \mathrm{~h}$, larvae were counted and unhatched 
eggs were returned to the original tube and stored at $25^{\circ} \mathrm{C}$ until the next flooding, which was set up seven days later. Chorions of eggs that remained unhatched after the second flooding were bleached with $50 \%$ commercial sodium hypochlorite solution to check viability. Embryos that were creamy white with eyespots, hatching spine, and distinct abdominal segmentation, were assumed to be viable. Yellow-brown or red-brown embryos were assumed to be nonviable (McHaffey \& Harwood 1970).

Data collected included: (1) percent of hatching; (2) eggs unhatched with dead embryos after two successive flooding; (3) spontaneous hatch after the previous flooding; (4) eggs collapsed after the previous flooding; and (5) eggs without embryos. The percentage of eggs hatching from each batch was calculated as the number of larvae after flooding/number of total eggs (hatched and un-hatched) $\mathrm{x} 100$, and each batch was treated as a replicate (Parker 1988). These percentages were arcsinetransformed before ANOVA using the Freeman-Tukey's transformation. Differences in the hatching response between treatments stored for 20 months were analyzed by Mann-Witney rank test. The percentage of hatched eggs from the first and second flooding were analyzed by a paired $t$ test. Differences in the hatching response among storage times in treatments stored at $5^{\circ} \mathrm{C}$ were analyzed by one-way ANOVA. When significant differences were detected by ANOVA, multiple comparisons of means were made using Tukey's honestly significant differences test for unequal data (Zar 1996).

Results of the present study show that spontaneous hatchings occurred in eggs that remained stored at both conditions, and increased when the storage time was long (Table I). These spontaneous hatchings could be attributed to water condensation during storage which stimulated the pharate larva to hatch. A similar pattern was observed for the percentage of collapsed eggs in relation to the storage time (Table I). On the other hand, the mortality of pharate larva after the second flooding, in both groups varied between 1.7 and 33\% and showed no relation with the storage time (Table I).

Viability (eggs hatched + eggs unhatched with embryo alive) of Oc. albifasciatus varied between 12 or 31 months if eggs were stored at room temperature or $5^{\circ} \mathrm{C}$ respectively. In the group of eggs stored at room temperature $13.8 \%$ of hatch was recorded but only in the treatment of 12 months storage. In contrast the group of eggs stored at $5^{\circ} \mathrm{C}$ hatchings was observed after the three storage times (Table I), and the percentage of hatched eggs decreased significantly $(\mathrm{F}=12.37, \mathrm{df}=2, \mathrm{p}<0.001)$ as time increased. Comparison between treatments stored during 12 months showed that the percentage of hatching eggs stored at $5^{\circ} \mathrm{C}$, was significantly higher than that of eggs stored at room temperature $\left(T_{(20,20)}=299, p=0.003\right)$ (Table I). Ludueña-Almeida and Gorla (1995) observed that Oc. albifasciatus eggs stored at drought condition survive for six months, decreasing their viability as time increase. Our result show that mortality increases when the storage time is long, independent of storage conditions.

In this study the treatments that required two floodings to hatch were the eggs stored for 12 and 18 months at $5^{\circ} \mathrm{C}$. The number of hatched eggs during the second flood $\left(\mathrm{n}_{\text {(Treat.12) }}=3, \mathrm{n}_{\text {(Treat.18) }}=109\right)$, was significantly lower (Paired: $\mathrm{t}$ (Treat. 12) $=5.18, \mathrm{df}=15, \mathrm{p}<0.001$; $\left.\mathrm{t}_{\text {(Treat. 18) }}=2.99, \mathrm{df}=11, \mathrm{p}=0.012\right)$ than hatched eggs from the first flood $\left(\mathrm{n}_{(\text {Treat.12) }}=934, \mathrm{n}_{\text {(Treat. 18) }}=586\right)$ (Table II). All eggs stored at room temperature hatched during the first flooding while a few eggs stored at $5^{\circ} \mathrm{C}$ hatched after the second flooding (Table II). This installment hatching behavior observed in the treatment at $5^{\circ} \mathrm{C}$ was reported previously in a study where some eggs after being stored and flooded during winter required up to three consecutive flooding to hatch, while eggs flooded in spring hatched during the first flooding (Campos \& Sy 2006).

I concluded then that (1) Oc. albifasciatus eggs are able to survive and hatch over 31 months; (2) the percent hatching of eggs stored at $5^{\circ} \mathrm{C}$ is higher than that of eggs stored at room temperature; (3) low temperatures and long dry periods favor installment hatching.

\section{ACKNOWLEDGMENTS}

To Lic. Victoria Sy (ILPLA) for help with the field and laboratory works, Dr. Arnaldo Maciá (Centro de Estudios Parasitológicos y de Vectores UNLP-CONICET), and anonymous reviewers for their comments which greatly improve this manuscript.

TABLE I

Percentage of Ochlerotatus albifasciatus eggs (from 20 batches by treatments), that hatched after being stored at two temperature conditions for three storages periods

\begin{tabular}{|c|c|c|c|c|c|c|}
\hline \multirow{4}{*}{ Eggs } & \multicolumn{6}{|c|}{ Storage condition } \\
\hline & \multicolumn{3}{|c|}{ Room temperature } & \multicolumn{3}{|c|}{$5^{\circ} \mathrm{C}$} \\
\hline & \multicolumn{3}{|c|}{ Months } & \multicolumn{3}{|c|}{ Months } \\
\hline & 12 & 18 & 31 & 12 & 18 & 31 \\
\hline Hatched after two successive flooding & 13.8 & 0 & 0 & 41.5 & 33.4 & 0.1 \\
\hline Unhatched with embryo (dead) & 33 & 29.5 & 14.7 & 18.2 & 1.7 & 11.6 \\
\hline Spontaneous hatch previous flooding & 8.1 & 12.8 & 14.4 & 3.7 & 9.9 & 12.6 \\
\hline Collapsed (with and without embryo) & 38.5 & 51.9 & 54.9 & 31.5 & 29.8 & 46.7 \\
\hline Without embryo & 6.6 & 5.8 & 16 & 5.1 & 25.2 & 29 \\
\hline
\end{tabular}


TABLE II

Number of Ochlerotatus albifasciatus eggs (from 20 batches per treatment) that hatched in two successive flooding, after being stored at two temperature conditions for three dry periods

\begin{tabular}{|c|c|c|c|c|c|c|}
\hline \multirow{4}{*}{ Flooding } & \multicolumn{5}{|c|}{ Storage condition } & \\
\hline & \multicolumn{3}{|c|}{ Room temperature } & \multicolumn{3}{|c|}{$5^{\circ} \mathrm{C}$} \\
\hline & \multicolumn{3}{|c|}{ Months } & \multicolumn{3}{|c|}{ Months } \\
\hline & 12 & 18 & 31 & 12 & 18 & 31 \\
\hline $1 \mathrm{st}$ & 278 & 0 & 0 & 934 & 586 & 3 \\
\hline 2nd & 0 & 0 & 0 & 3 & 109 & 0 \\
\hline
\end{tabular}

\section{REFERENCES}

Andreadis TG 1990. Observations on installment eggs hatching in the Brown Salt marsh mosquito, Aedes cantator. J Am Mosq Control Assoc 6: 727-729.

Breeland SG, Pickard E 1967. Field observations on twenty-eight broods of floodwater mosquitoes resulting from controlled flooding of a natural habitat in the Tennessee Valley. Mosq News 27: $343-358$

Campos RE, Sy VE 2006. Variation in the hatching response of Ochlerotatus albifasciatus egg batches (Diptera: Culicidae) in temperate Argentina. Mem Inst Oswaldo Cruz 101: 47-53.

Campos RE, Sy VE 2007. Effects of continuous drought and immersion on hatchability of Ochlerotatus albifasciatus (Diptera: Culicidae) eggs exposed to low temperature. Rev Soc Entomol Argent 66: $131-136$

Christophers SR 1960. Aedes aegypti (L.) the yellow fever mosquito: Its life history, bionomics and structure, Cambridge University Press, London, 739 pp.
Fava FD, Ludueña Almeida FF, Almirón WR, Brewer M 2001. Winter biology of Aedes albifasciatus (Diptera: Culicidae) from Córdoba, Argentina. J Med Entomol 38: 253-259.

Forattini OP, Sallum MAM, Kakitani I 1988. Catálogo das coleções Entomológicas da Facultade de Saúde Pública da Universidade de São Paulo (2 ${ }^{\mathrm{a}}$ série II) Culicidae. Rev Saúde Publ 22: 519-547.

Gjullin CM, Yates WW, Stage HH 1950. Studies on Aedes vexans (Meig.) and Aedes sticticus (Meig.), flood-water mosquitoes, in the lower Columbia River Valley. Ann Entomol Soc Am 43: 262-275.

Gubler DJ 1970. Comparison of reproductive potentials of Aedes (Stegomyia) albopictus Skuse and Aedes (Stegomyia) polynesiensis Marks. Mosq News 30: 201-209.

Ludueña-Almeida FF, Gorla DE 1995. The biology of Aedes (Ochlerotatus) albifasciatus Macquart, 1838 (Diptera: Culicidae) in Central Argentina. Mem Inst Oswaldo Cruz 90: 463-468.

Maciá A, García JJ, Campos RE 1995. Bionomía de Aedes albifasciatus y Ae. crinifer (Diptera: Culicidae) y sus enemigos naturales en Punta Lara, Buenos Aires. Neotrópica 4: 43-50.

McHaffey DG, Harwood RF 1970. Photoperiod and temperature influences on diapause in eggs of the floodwater mosquito Aedes dorsalis (Meigen) (Diptera: Culicidae). J Med Entomol 7: 631-644.

Mitchell CJ, Monath TP, Sabattini MS, Daffner JF, Cropp CB, Calisher CH, Darsie Jr RF, Jakob WL 1987. Arbovirus isolations from mosquitoes collected during and after the 1982-1983 epizootic of Western Equine Encephalitis in Argentina. Am J Trop Med Hyg 36: $107-113$

Parker BM 1988. Photoperiod-induced diapause in a North Carolina strain of Aedes sollicitans: Photosensitivity of fully formed and developing embryos. J Am Mosq Control Assoc 4: 57-62.

Rossi GC, Lestani EA, D’Oria JM 2006. Nuevos registros y distribución de mosquitos de la Argentina (Diptera: Culicidae). Rev Soc Entomol Argent 65: 51-56.

Zar JH 1996. Biostatistical Analysis, 3rd ed., Prentice Hall, New Jersey, $718 \mathrm{pp}$. 